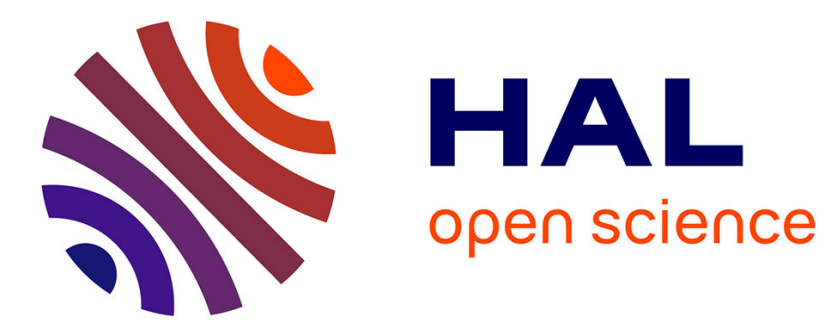

\title{
The Japanese Consumer Finance Market and its Institutional Changes since the 1980s
}

\author{
Adrienne Sala
}

\section{To cite this version:}

Adrienne Sala. The Japanese Consumer Finance Market and its Institutional Changes since the 1980s. 2017. halshs-02088335

\section{HAL Id: halshs-02088335 \\ https://shs.hal.science/halshs-02088335}

Preprint submitted on 2 Apr 2019

HAL is a multi-disciplinary open access archive for the deposit and dissemination of scientific research documents, whether they are published or not. The documents may come from teaching and research institutions in France or abroad, or from public or private research centers.
L'archive ouverte pluridisciplinaire HAL, est destinée au dépôt et à la diffusion de documents scientifiques de niveau recherche, publiés ou non, émanant des établissements d'enseignement et de recherche français ou étrangers, des laboratoires publics ou privés.

\section{(1)(1) $\$(0)$}

Distributed under a Creative Commons Attribution - NonCommercial - ShareAlikel 4.0 

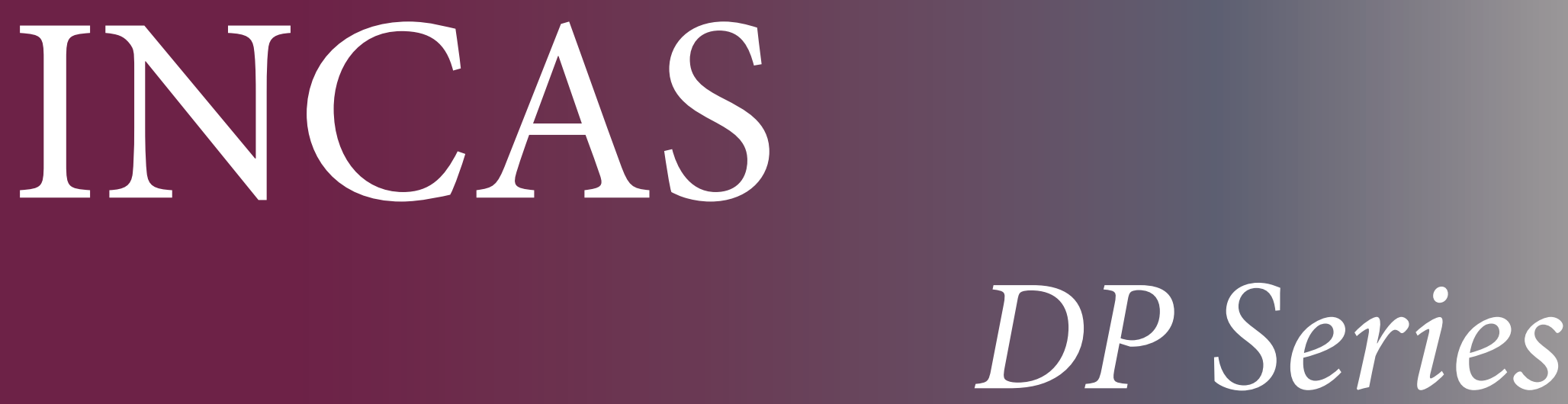

Discussion Paper Series 2019 \#03

\section{The Japanese Consumer Finance Market and its Institutional Changes since the 1980s}

April 2019

Adrienne Sala

Sciences Po Lyon

This work has received funding from the European Union's Horizon 2020 research and innovation programme under the Marie Skłodowska-Curie grant agreement No 645763.

IN C A S

Understanding institutional change in Asia: a comparative perspective with Europe

http://incas.hypotheses.org/

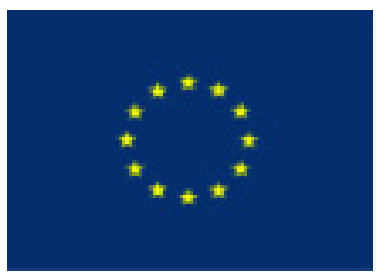




\section{ABOUT THE INCAS PROJECT}

INCAS is a Marie Skłodowska-Curie Actions R.I.S.E funded project under the European Commission's H2020 Programme.

The project INCAS aims at creating a top-level research and advanced training network on institutional change in Asia, in comparative perspective with Europe.

The coordinator, Ecole des Hautes Etudes en Sciences Sociales (France), promotes this network together with Oxford University (UK), Freie Universität Berlin (Germany), and in collaboration with Waseda University (Japan). The aim of the proposed mobility scheme is to give birth to a European consortium and network of faculties and advanced graduate students specialized in the comparative analysis of institutional change in Asia and Europe. The partners have chosen Japan as a reference point because of its comparability with Europe as shown by previous studies, its historical influence on development and further institutional changes in Asia, and the expertise accumulated within our research team.

Analyzing current economic dynamics in Japan and later expanding this analysis to other Asian countries promises to generate insights that might be help to better understand challenges for Europe and to prepare relevant policy proposals. Our purpose is to compare the results obtained in the case of Japan and few other Asian countries (South Korea, Taiwan, China, and possibly Thailand, after having checked the data availability), not only to previous results on Europe but also to original results we will get on European countries (primarily France - which will be our reference country in Europe - and then the UK, Germany, and Italy) in mobilizing new historical data and applying our theoretical framework. 


\title{
The Japanese Consumer Finance Market and its Institutional Changes since the 1980s
}

April 2019

Adrienne Sala

Sciences Po Lyon

\begin{abstract}
In this article we assert that the joint transformation of public perception about households' over-indebtedness and financial deregulation had important implication on the government decision to reform the overall consumer credit between 2005 and 2010. On the one hand, the development of collective actions by groups of lawyers to defend borrowers from moneylenders' abusive practices represents a source of change in the public opinion about over-indebted individuals in a context of long economic stagnation. A systematic press articles' analysis from 1977 to 2006 shows that the rising number of these collective actions since the early 1990s may have gradually increased the political salience of social issues related to the unsecure loan market. On the other hand, financial deregulation has been a source of change by allowing banks to enter the consumer finance market since the early 2000s. Banks entry on this market transformed the logic of complementarity among traditional consumer credit's actors (Shinpan, credit card companies and sarakin) in a general context of legal consumers protection's reinforcement. Thus evolution of the Japanese consumer finance's regulation is particularly relevant to illustrate forces of institutional change and its consequences.
\end{abstract}

\section{Keywords}

Consumer finance, institutional change, political salience, over-indebtedness, collective actions, lawyers

\section{Acknowledgment}

A later version of this article has been published in Japan Forum, Volume 29, 2017. 


\section{Introduction}

Since the 1980s, excessive household debt has gradually become a serious social and political challenge in many advanced countries. The number of personal bankruptcies increased in the United States as well as in countries with a more "conservative" private debt policy such as France and Germany ${ }^{1}$. Also many governments responded by revising their insolvency procedure in order to ease the process and at the same time reduce the social stigma attached to personal bankruptcy (Partner, 1995; White, 2003). In comparison, in Japan scholarly interest both in consumer credit and households' over-borrowing has been relatively low until recently. The three most common explanations are that until the end of the 1990s, the Japanese economy was characterized by a high rate of saving (Horioka, 1990); Japanese households hate getting into debt partly due to the social trauma attached to personal bankruptcy (Mann, 2007); and Japanese banks were late in entering the consumer credit market (Horioka, 1990; Hoshi \& Kashyap, 2004) ${ }^{2}$. In fact, during the lost decade (1992-2004), on aggregate level, debt driven consumption did not increase among Japanese households and the ratio of debt to income remained stagnant since the early $1990 \mathrm{~s}^{3}$, as Japanese households used their savings to maintain a certain level of consumption (Kobayashi, 2010). However, according to the Nichibenren annual reports, since the mid-1990s households' indebtedness increased among lower income bracket as a result of over-borrowing on the non-bank unsecure loan market ${ }^{4}$. In 2006, in order to solve the over-borrowing and excess of lending problem (tajûsaimu), the Koizumi's government implemented the revision of the Moneylenders Business Law (kashikingyô hô, 1983) to reinforce the regulation of the overall consumer finance market.

The 2007-2008 subprime loan financial crisis contributed to a renewed interest regarding consumer credit and more broadly the history of American capitalism (e.g. Hyman, 2011; Graeber, 2011), whereas after the burst of the housing and financial bubble (1989-1991) the rise of Japanese consumer finance market and increase of personal bankruptcies did not triggered the same level of interest among social sciences scholars. Nevertheless, the new Moneylenders' business law (kaisei kashikingyô hô) voted in 2006 and fully implemented in 2010 has been analyzed, especially among jurists. They emphasize the role of the judiciary power in the government's decision to reform the consumer finance market and they also stress the lower bargaining power of Consumer Finance Companies (the so-called sarakin), which I shall refer to as CFCs (Kozuka \& Nottage, 2007, 2009; Pardieck, 2008; Ramseyer, 2013). These studies contribute to the consumer credit literature by shedding light on the Japanese case in comparative analysis. But the process of institutional change that occurred in this market historically dominated by moneylenders ${ }^{5}$ is yet to be analyzed. Indeed moneylenders were organized into groups of pressure enjoying a high political influence in contrast with the lack of borrowers' political representation (weak interest). Moneylenders including CFCs developed informal practices of lending due to an ambiguity of the consumer finance regulation. Besides, the lack of a legal concept of "over-indebtedness", the low level of consumers' legal protection in the financial sector and the unfriendly insolvency procedure until the end of the 1990s, allowed several moneylenders to conduct abusive lending practices.

In this article we analyze the institutional transformations of the Japanese consumer finance market by focusing on the evolution of the moneylenders business' regulation since the late 1970s to the late 2000s. By emphasizing the gap between formal rules and informal practices we look at the rise of several social issues, especially households overindebtedness leading to personal bankruptcy. We analyze more precisely the collective actions organized by groups of lawyers to help indebted persons by providing financial and legal counseling services and how their actions changed the public opinion's perception about over-indebted individuals.

\footnotetext{
1 Louis R. Hyman, « Debtor Nation: A History of America in Red Ink », Politics and Society in the Twentieth Century series, Princeton University Press, 2011, ; Entreprise \& Histoire, Consommer à crédit en Europe au XX ${ }^{\mathrm{e}}$ siècle, $\mathrm{n}^{\circ}$ 59, 2010/2, The Development of Consumer Credit in Global Perspective, Business, Regulation, and Culture, Worlds of Consumption ", Edited by Jan Logemann, Palgrave Macmillan, 2012; G. Bertola, R. Disney, C. Grant (2006) « The Economics of Consumer Credit »; MIT press, Cambridge ; J. Niemi, I. Ramsay, W.C. Whitforf (2009) « Consumer Credit, Debt and Bankruptcy. Comparative and International Perspectives», Hart Press Ed., Oxford; Warren \& Sullivan, The fragile middle-class : American in debt, Yale University Press, 2001; Trumbull G. (2014) "Consumer Lending in France and America", Cambridge University Press; David Kraft, Private Law Control of Consumer Credit in the United Kingdom' in Christian Twigg-Flessner et al (eds), Yearbook of Consumer Law 2008 (Ashgate, 2007) 403.

2 Hayashi, F. (1986), Why Is Japan's Saving Rate So Apparently High? in Stanley Fischer, ed., NBER Macroeconomics Annual, vol. 1, Cambridge, Massachusetts: MIT Press; Horioka, C.Y. (1993), Consuming and Saving in Andrew Gordon (ed.) Postwar Japan as History, Berkeley: University of California Press; Horioka, C.Y. (1995), Is Japan's Household Saving Rate Really High? Review of Income and Wealth, series 41, no. 4; Ronald, M.J. (2002), Credit Cards and Debit Cards in the United States and Japan, Vanderbit Law Review, Vol. 5

3 Nomura Japanese Economic Research (November, 2002) https://www.nri.com/global/news/2002/021119/021119.pdf (BOJ, Flow of funds / and Family Income and Expenditure Survey)

$4 \quad$ Japan Federation of Bar Associations (Nichibenren) reports available for 1994, 1997, 2002

$5 \quad$ Although the CFCs objected to many of the measures proposed by the government regulatory policies, such as the ceiling on interest rates, it seems that they were excluded from the policy process (Trumbull, 2012)
} 
The article is built as follows. In section 1, we discuss the literature on consumer credit and introduce briefly the concept of political salience. In section 2, the chronological and historical perspective allows us to analyze in parallel the rise of the consumer finance market as well as social issues related to over-indebtedness. Section 3 analyzes the evolution of the public debate about the sarakin mondai with a particular focus on collective actions organized by borrowers' advocates and its press coverage. A final section provides a conclusion.

\section{Literature on consumer credit and political salience}

This section engages with the literature on consumer credit and personal bankruptcy by focusing on process of institutional changes that affected the historical complementarity between bank and non-bank sectors in Japan. We also propose to connect the literature on collective actions and social mobilization to analyze the rising influence of lawyers who represented the borrowers' interest on the legislative and judiciary arenas.

\subsection{The Japanese consumer credit}

Study of informal small loans in rural popular finance (shômin kinyû) has been widely analyzed in the Japanese economic and financial history literature. Historically moneylenders assumed an important role as an alternative form of informal credit to peasants, individual entrepreneurs and family business (Shibuya, 1972; 2001). Pawnshops also developed in urban areas in the beginning of the $20^{\text {th }}$ century taking opportunities from the rise of the consumer society and lack of regulation (Shibuya, 1972; Sala, 2015). In the postwar period, many shichiya changed their core business to enter the new market of unsecure personal loan (sarakin) but research about this market and its development faded. In comparison, installment sales credit has been much more analyzed especially by historians. Gordon (2006) shows how consumer credit companies developed in the prewar period in collaboration with department stores to propose installment sales credit to the emerging middle-class consumers. Since the 1950s, consumer credit companies developed new credit facilities to consumers with bank account ${ }^{6}$ (Partner, 1999; Gordon, 2012). The apparent paradox between Japanese households' high saving rate and the rise of consumerism is partly due to this easy-access to consumer credit during the high economic and income growth period (Partner, 1999). Simon Partner shed light on the gap between lower and higher income households' access to mass consumer society as lower income households had very few savings and bought consumer durables on credit whereas higher income could be both saver and consumer. These studies show that economic and social history of the Japanese consumption society is closely related to consumer credit's development in continuity with the prewar period (Gordon, 2012; Hunter \& Franck, 2011). In many ways consumer credit sustained the rise of mass consumption as we observed in other industrialized countries (Calder, 1999; Glickman, 1999), but the Japanese consumer credit market also shows several institutional characteristics.

\subsection{Institutional characteristics of the Japanese consumer credit}

We observe a historically low participation of banks except during the bubble period of the late 1980s and a highly segmented overall market depending on the type of credit provided (credit card, installment sales, unsecure loan, mortgage loan). This segmentation has reduced the consumer credit market's efficiency by creating niche markets under different regulation and public authority's supervision. Adding to those specific aspects of regulatory and economic landscape, the lack of a centralized credit bureau has contributed to increase the risk of over-borrowing as well as excess of lending from small loan lenders who charged legally high interest rates. Although in comparison to other industrialized countries, Japanese households' ratio of debt to income was low until the end of the 1970s; it significantly increased during the 1980s and then, stabilized during the 1990s (Horioka, 2012; Lebarz, 2014). Nevertheless, we observe a paradox between the aggregate level of secure households debt and the micro level data showing a rapid increase in the number of bankruptcies filling in the late 1990s following the reform of the insolvency law (19962004). A study of personal bankruptcies' factors reveals that the majority of cases are related to over-borrowing on the unsecure loan market (sarakin) (Higuchi \& Banno, 2004). Since the 1980s, groups of lawyers within the Nichibenren (Japan Federation of Bar Associations) has carried out several lobbying campaigns demanding more stringent small loan regulation to protect borrowers from excess of lending at high interest rate on the unsecure loan market. 


\subsection{Collective actions and political salience of Japanese households' over-indebtedness}

In the typology of group of interest's coalition, Japan is characterized by a State and Industry coalition that reduces the civil society's influence over policy makers (Stigler, 1971; Trumbull, 2014). This approach is nuanced by others studies specific to the Japanese case of consumers protection. For example Maclachlan (2002) argues that, in the rare cases where interests of politics, bureaucrats and industry are in conflict, consumers group can find a way to voice their grievances in the public arena and gain political support. However, when there is a strong cohesion of interests between those three groups (politics, bureaucrats and industry), the government pays little heed to consumers group, even when the public supports them. Calder (1988) highlights a very similar process in favor of consumers during period of economic crisis in contrast to the general tendency of the Japanese government to privilege producers over consumers. Nevertheless these studies did not mention how to measure the evolution of the public opinion's interest for the consumers' cause. For example, the concept of political salience gives insights on the variation of the public interest by identifying the importance of a subject for the average voters in comparison with other political issues (Kollman, 1998). In a context of high salience of a particular issue, political parties will begin to pay attention to that issue, as will public opinion (Baron, 1994). In this context, interest groups will also start launching campaigns to mobilize public interest (Kollman, 1998). Based on a large volume of literature concerning interest groups and collective actions, Culpepper shows that in a context of low political salience, concentrated interests have more influence over politics than diffuse interests (Olson, 1965; Wilson, 1973, Culpepper, 2011). The next question, then, is how does a matter of low salience become a matter of high salience? Wilson (1980) argues that public interest can be mobilized more effectively when scandals are covered by medias especially in period of economic crisis. The level of media coverage of an issue provides politicians with an indicator to understand which information the public cares about (Patterson, 1993). This dynamic approach is helpful to understand how during the 1990s collective actions organized by lawyers and covered by medias, influenced gradually the political salience of social issues related to CFCs and small lenders' informal and abusive practices leading to several scandals.

\section{The rise of Japanese consumer finance market}

In the postwar period, banks focused on secured business loans and had little interest in consumer credit. The 1950s saw the emergence of moneylenders, known as danchi kinyu (condominium finance), who followed in the legacy of the traditional shômin kiny $\hat{u}$ (popular finance) (Shibuya, 2001). Moneylenders could take advantage of a gray zone, created by the legal gap between the interest rate ceiling of $20 \%$, set by the Interest Rate Restriction Act (IRRA, No 100, 1954) under the civil code and the 109,5\% ceiling for the interest rate set by the Investment, Deposit and Interest Rates Act (IA No 195, 1954) under the penal code. Both of these laws governed the consumer finance industry. In the 1960s, the number of urban small lenders increased rapidly in a context of consumer and wage-based society's boom. Consumer finance companies provided small and unsecured loans to wage earners. These companies were called sarakin, a popular abbreviation of 'salaryman' + 'loan' (kiny $\hat{u})$. They provided loans that required only an identification card and a selfdeclaration of income. The market was virtually unregulated, and continued to grow during the 1970s and the 1980s, dominated by four major consumer finance companies, Promise, Acom, Takefuji and Aiful, but also including a large number of small lenders in charge of proving loans to individual entrepreneurs, family business, and retailers (Tapals, 2001).

\subsection{Social issues and legislation's ambiguity}

During the 1970s, numerous scandals involving high interest lending practices and harsh collection tactics forced the Ministry of Finance (MoF) to adopt regulatory measures in order to address the problem known as sarakin mondai, associated with over-borrowing, usury and illicit practices, which in the worst cases led to debt-related suicides ${ }^{7}$. After almost six years of debate, the Money Lending Business Law (MLBL) was passed in 1983 as proposed by the Liberal Democrat Party (LDP). The law set an objective to reduce over time and at "a future date" the maximum interest rate at $40.0004 \%$. The law also enacted the "voluntary payment provisions" ${ }^{8}$ that remained in force until the Supreme Court definitely rules against the application of this provision in 2004 (Pardieck, 2008) (see figure 1).

$7 \quad$ Asahi article 1978/10/13

8 The IRRA capped maximum interest rates at 20\%, depending on the amount of the principal, although article 1 mentions that "The agreement on interest shall be null and void with regard to the portion which is in excess". Paragraph 2, however, states: "Where the debtor has voluntarily paid a portion in excess... he may not demand the refund thereof...", thus leaving plenty of room for "voluntary payment"; Pardieck, 2008. This practice was strongly criticized by the judiciary power since the Supreme Court rulings in 1964 and 1968. 


\section{Figure 1. The grey zone of lending from 1954 to 2010}

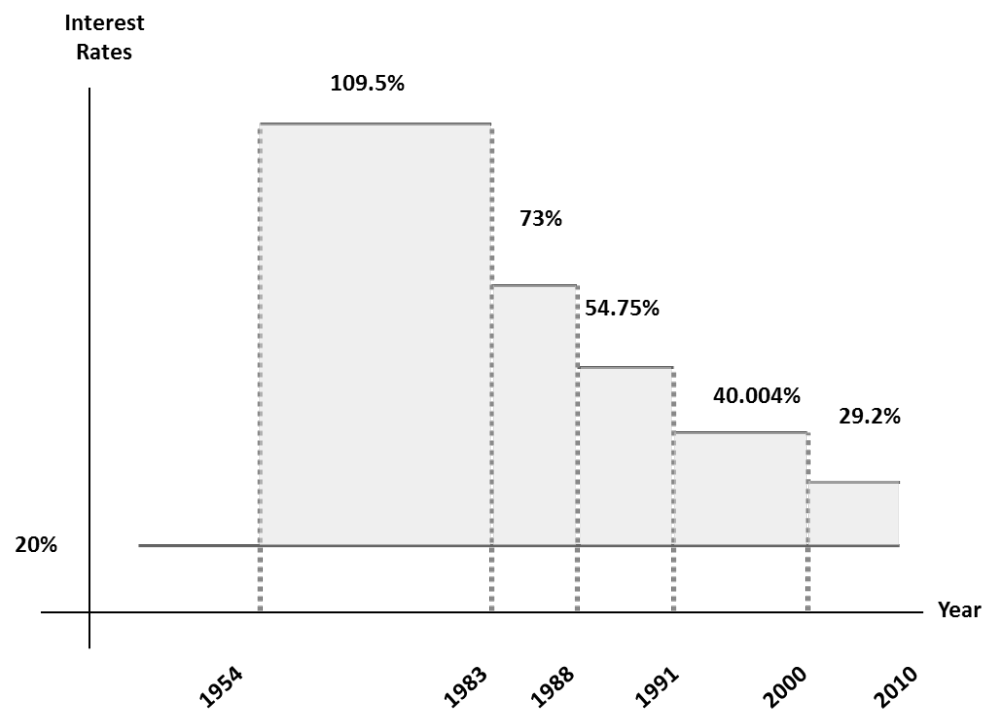

Source: FSA

Opposition parties and several lawyers argued that the law was likely to enlarge the usury pot and was tilted towards protecting the interests of moneylenders ${ }^{9}$. Rules were established in favor of moneylenders' interests, resulting in selfregulatory measures and upholding of the Supreme Court's decisions (1964 and 1968) in favor of borrowers' protection. An accurate study of the Upper house finance committee preceding the vote of the law proposed by the deputy Ohara (DPL) shows that despite their presence in the legislative arena, borrowers' defense groups (consumers associations and lawyers) could not voice their arguments in favor of a more protective legislation for borrowers and a lower interest rate cap ceiling by abolishing the gray zone. The final law was unpopular with scholars and lawyers involved partly because of the provision in Article 43 stating that, where the borrower "voluntary paid interest" in excess of the maximum interest rates and the borrower received the necessary documentation, that payment would be "deemed a valid payment of interest on the debt". ${ }^{10}$ The article 43 was designed to allow lenders to continue charging higher interest rates during an unspecified period of time. The political collusion between the conservators (DPL) and the CFCs (sarakin) was highly criticized in the newspapers ${ }^{11}$.

The historical informal complementarity between bank and non-bank sectors, which consisted in addressing the demand of credit from high-risk borrowers (SMEs, VSEs, entrepreneurs and family business) to whom banks could not lend, was re-used in the early 1980s to let CFCs make profits by lending large amount of personal loan at high interest rate to a wider range of consumers. Since the late 1970s and despite the historical complementarity with non-bank lenders, banks attempted to expand the consumer credit market and shape consumer demand. They became strong advocates of credit access policies. The MoF encouraged banks to practice consumer lending, and revised the banking law in 1984. This coalition was also intended to help shaping the consumer finance market by pushing illicit small loan lenders out of the market ${ }^{12}$. By the mid-1980s consumer credit became more universal and competitive, resulting in a reduced number of peripheral players. For a short period of time, banks became key players in consumer finance and increased their market share on the personal loan sector, whereas CFCs experienced a significant decrease of their business (Cf. Table 1). The debt (including consumer credit and housing loans) to disposable income ratio increased steadily up to the 1990s (e.g: 77\% in 1980, 88,8\% in 1985 and 131,5\% in 1990). ${ }^{13}$ Different factors account for this: growth of personal income, demand for consumer durables, availability of technology providing a better management of credit transactions, as well as financial institutions looking for underdeveloped market for their accumulated funds (Alexander \& Kong, 1989).

$9 \quad$ Nikkei article 21/03/1983; Asahi article 30/04/1983

10 Kashikingyô no kisei nado ni kansuru hôritsu (The Money Lending Industry Regulation Act, Law No.32, 1983) http://law.e-gov.go.jp/ htmldata/S58/S58HO032.html

11 Asahi shinbun Article 1978/6/15; Article 1978/6/17; Article 1983/09/01; article 1983/09/02; article 1983/10/20 ; 1984/09/04 ; 1984/11/12

12 Shôhisha shinyô no arikata ni tsuite - kinyûseidô chôkai senmon iinkai hôkoku, zaikei shôhosha, 1987

13 OECD Economic Outlook, no. 54 (December 1993) in Horioka C.Y. (2012), Are Japanese Households Financially Healthy, and If So, Why? A Group of Seven (G7) Comparison, November 25, 2012, Discussion Paper No 859, Forthcoming in The Japanese Economy, vol. 39, no. 4 (Winter 2012/13). 


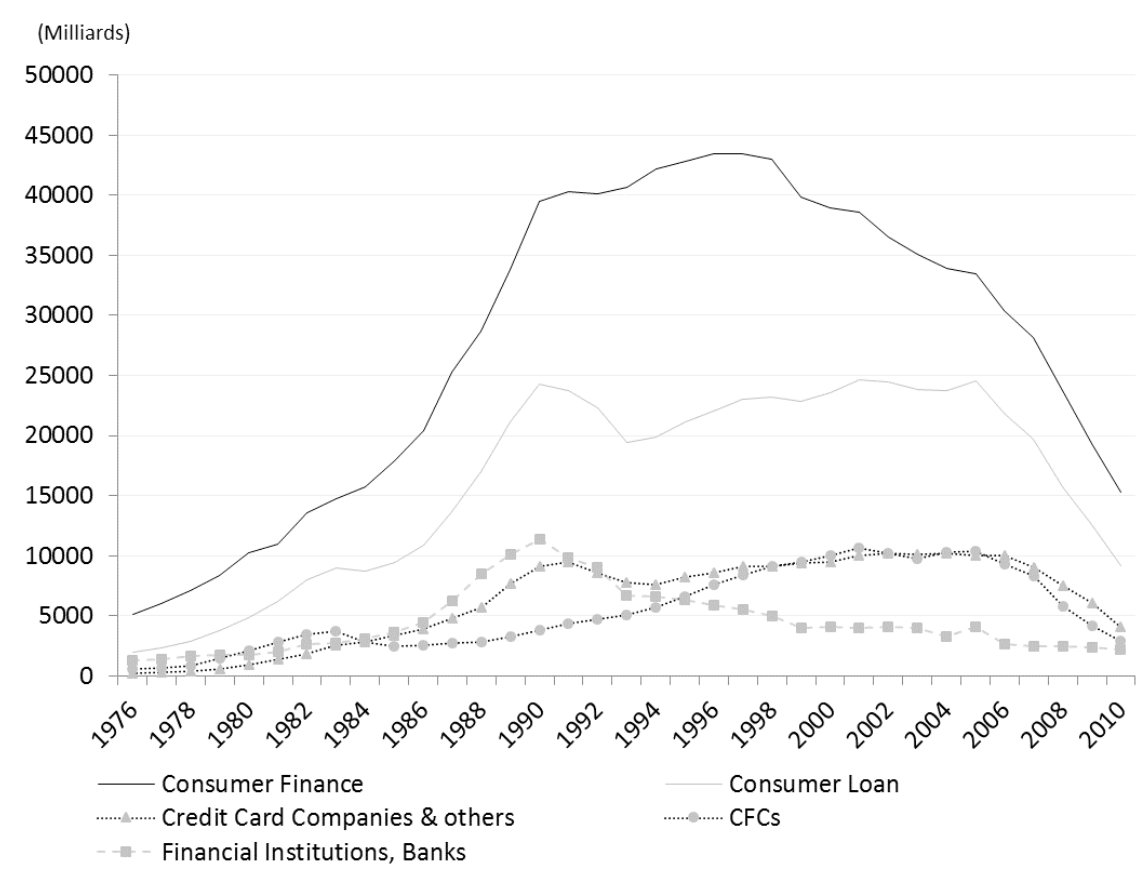

Source: Annual reports of the Japan Consumer Credit Association

At the end of the 1980s the overall consumer finance market increased significantly as well as credit card debt and subprime loans ${ }^{14}$. After the bubble burst, over-indebtedness and personal bankruptcy increased rapidly in a deflationary and economic downturn period ${ }^{15}$. Banks rationed consumer credit, thus providing new market opportunities for consumer finance companies (CFCs) to develop their own markets. Unsecured loans increased again during the socalled lost decade (1992-2004). During this period, CFCs and commercial banks developed strong financial ties and re-enacted the traditional institutional complementarity. The burst of the bubble in a virtually unregulated market led to unintended consequences in favor of Consumer Finance Companies.

\subsection{Rise of Consumer Finance Companies during the lost decade}

After the bubble burst, the relationship between banks and CFCs changed as banks' market shares dramatically decreased on the consumer finance market and CFCs' market shares significantly increased ${ }^{16}$ (See table 2).

In 1991, in response to several financial scandals, which occurred during the bubble period, the government revised the Investment Act by lowering the ceiling to $40.0004 \%$. As compensation to moneylenders, the MoF authorized CFCs to raise funds directly on the financial market by issuing commercial paper (CP) and bonds. Then in 1999, the revision of the Non-Bank Bond Law allowed the CFCs with capital in excess of 1 billion yen to issue corporate bonds ${ }^{17}$. They were registered as Certified Finance Corporations. During the mid-1990s the major CFCs were also listed on the Tokyo Stock Exchange and by the end of the 1990s, they were accepted into the Keidenren. ${ }^{18}$ According to Forbes' ranking of the wealthiest people in 2004, there were four top CFC's directors ranking second, fifth, sixth and tenth. ${ }^{19}$ By the 1990s, banks and CFCs had built strong financial ties, banks became the CFCs' principal fund suppliers, lending to them at low interest rates (1.70\% and 2.50\%), joining them as shareholders. ${ }^{20}$ The rise of the CFCs can be attributed to their business model, characterized by a strategy of aggressive credit distribution based on high volume to high-risk borrowers.

\footnotetext{
$14 \quad$ Article Nikkei 1984/11/10

15 Article Asahi 1991/10/09; Article Asahi 1991/10/17; Article Asahi 1991/10/20

16 During the 1970s and 1980s, CFCs experienced difficulties in raising funds as a result of the negative image associated with moneylending. In addition to this, at the beginning of the 1980s, banks and CFCs had diverging interests on the consumer finance market, as banks started to show their willingness to enter this profitable sector. The MoF sent several informal warnings (tsutatsu) to the banking sector requesting them to lower interest rates on their loans to the CFCs.

17 Promise Co, Ltd, Annual report, 1996, 1997, 1998, 1999, 2000

18 Acom Co. Ltd, Aiful Co. Ltd, Promise Co, Ltd, Annual Report, 1999, 2000

19 Kamata S. "Les classes fortunées au Japon de Meiji à nos jours » in La dynamique du Japon, sous la direction de Jean-François Sabouret, Saint Simon Ed. 2005

20 In 2004, bank financing still represented the major source of funding for the major CFCs. Promise had strong financial ties with the Long-Term Credit Bank of Japan, Sumitomo Trust and Banking (Promise Co, Ltd. Annual Report, 2005)
} 


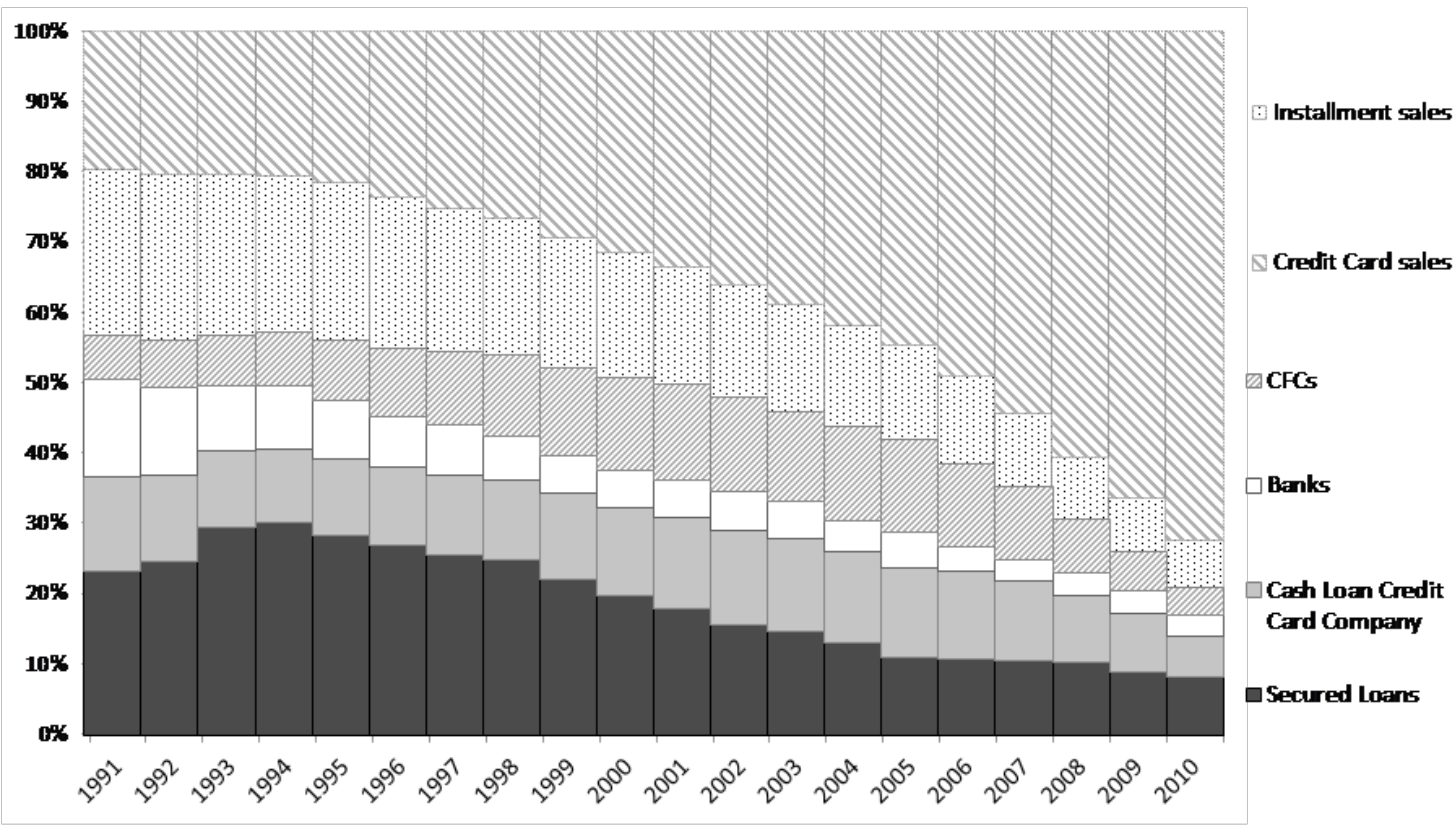

Source: Annual reports of the Japan Consumer Credit Association

At the beginning of the 1990s, advances in telecommunications transformed the economic logic of the sector. CFCs developed an Automatic Teller Machine distribution system to provide credit contracts. This new system increased the number of new clients, lowered the cost of credit, and enhanced easy-access credit. From 1998, the CFCs also improved their distribution network by using convenience store payment terminals and cash withdrawal systems. ${ }^{21}$ By the late 1990s, the CFCs had diversified their products strategy by increasing home equity loans, SME loans and equity funds, as well as credit cards. ${ }^{22}$ Promise formed an alliance with the Sanwa Bank (then UFJ) to launch Mobito, a consumer credit company targeting middle-risk consumers and in 2000, the Tokyo Mitsubishi Bank developed its credit card, Cash One, in association with Acom. During the same period, the government lifted the ban on advertising and the major CFCs developed more aggressive marketing and advertising campaigns in newspapers and on television. ${ }^{23}$

\subsection{Social issues and scandals in a period of economic downturn}

Since the 1990s the consumer finance market is an oligopolistic market with more than $70 \%$ of outstanding loans held by few major CFCs, even though more than $90 \%$ of the total number of lenders are small lenders and more than half of them lend money to $\mathrm{SMEs}^{24}$. Although the legislation is the same for all moneylenders, this highlights the strong heterogeneity of the market in terms of size and type of borrowers (consumers, SMEs). The role of the Money Lending Business Law was to set rules and regulation to establish control over the lenders. However, the self-regulatory provisions and the lack of government financial control led, again, to a virtually unregulated market. The Japanese government did not enforce any regulation to protect consumers who borrowed money. For example, borrowers' protection in the following three areas of credit market regulation was deficient: there was a lack of transparency in consumer credit contracts, a lack of provision to limit excessive or extortionate lending, and insolvency proceedings were overly long and costly. Although most of the advanced industrialized countries dramatically revised their personal insolvency law, beginning in the mid-1980s, the Japan Personal Insolvency Law was only revised in 1996 and fully implemented in 2004. The purpose of the revision was to facilitate the process of filing for personal bankruptcy and to reduce the social stigma associated with $\mathrm{it}^{25}$. Besides, there was no regulation of national credit rating agencies: there were four main credit bureaus and, in 2005, only 2079 out of 14000 registered moneylenders were members of a credit bureau federation. ${ }^{26}$ This meant that a large number of lenders were not using established credit bureaus and their borrowers were not included in official statistics ${ }^{27}$.

21 Acom Co. Ltd, Aiful Co. Ltd, Promise Co, Ltd, Annual Report, 1996,1997; 1998; 1999, 2000, 2001, 2002

$22 \quad$ Ibid

23 Kigaruni ni narenu sarakin CM, January, 8, 2002, Asahi Shinbun; « Sarakin CM » an-isanaika, (koe) January, 11, 2002, Asahi Shinbun.

24 Annual reports of the Japan Consumer Credit Association

25 Matsushita J. (2006), Comprehensive Reform of Japanese Personal Insolvency Law, Theoretical Inquiries in Law 7.2

26 See Pardieck, 2008

27 The lack of security and control is a problem not only for the unsecured credit market: the credit card market expansion, which began in the mid-1990s, is also suffering from an increase of frauds related to the low payment system 
In a context of economic stagnation and banking crisis, the 1990s bore witness to several scandals. As of 1998, when banks started to ration credit, unsecured loans to SMEs increased, as well as illicit and harsh practices leading to the so-called shôkôron mondai. The government took action by lowering the ceiling on interest rates to $29.2 \%$ in 2000 , but it did not abolish the gray zone, either did he revise the credit policy to provide better access to credit as well as legal protection for borrowers. In response to the lower ceiling on interest rates, large CFCs sought more volume in order to maintain their profits. Low regulation and lack of a centralized data system (credit bureau) led to an excess of lending: in the worst cases, borrowers were receiving credit from more than 10 lender $^{28}$. Debtors, who found themselves in trouble, having borrowed money from CFCs, often went to smaller lenders to borrow money to reimburse the previous loan, and in the worst cases they borrowed from predatory lenders, known as yamikin ${ }^{29}$.

\section{Collective actions and political salience}

Increase of over-indebtedness may threaten the expansion of the virtually unregulated consumer finance market as a result of an increasing general concern over the problem. In addition, the media coverage of the CFCs' high profits may also increase public sensitivity about the lenders' lack of morality. In the next section we analyze the press coverage for the sarakin mondai to emphasize the evolution of the public interest and its perception of the problem.

\subsection{Press coverage analysis- methodology ${ }^{30}$ and results}

We analyzed the press coverage for the sarakin mondai from 1977 to 2006 by selecting articles from Asahi shinbun and Nikkei shinbun. We made a research by key word "sarakin" and obtained more than 4000 articles. We chose to keep the term "sarakin" instead of consumer finance (shôhisha kiny $\hat{u}$ ) as "sarakin" describes the reality of moneylenders' abusive practices $^{31}$.

Figure 2: Evolution of sarakin mondai's salience

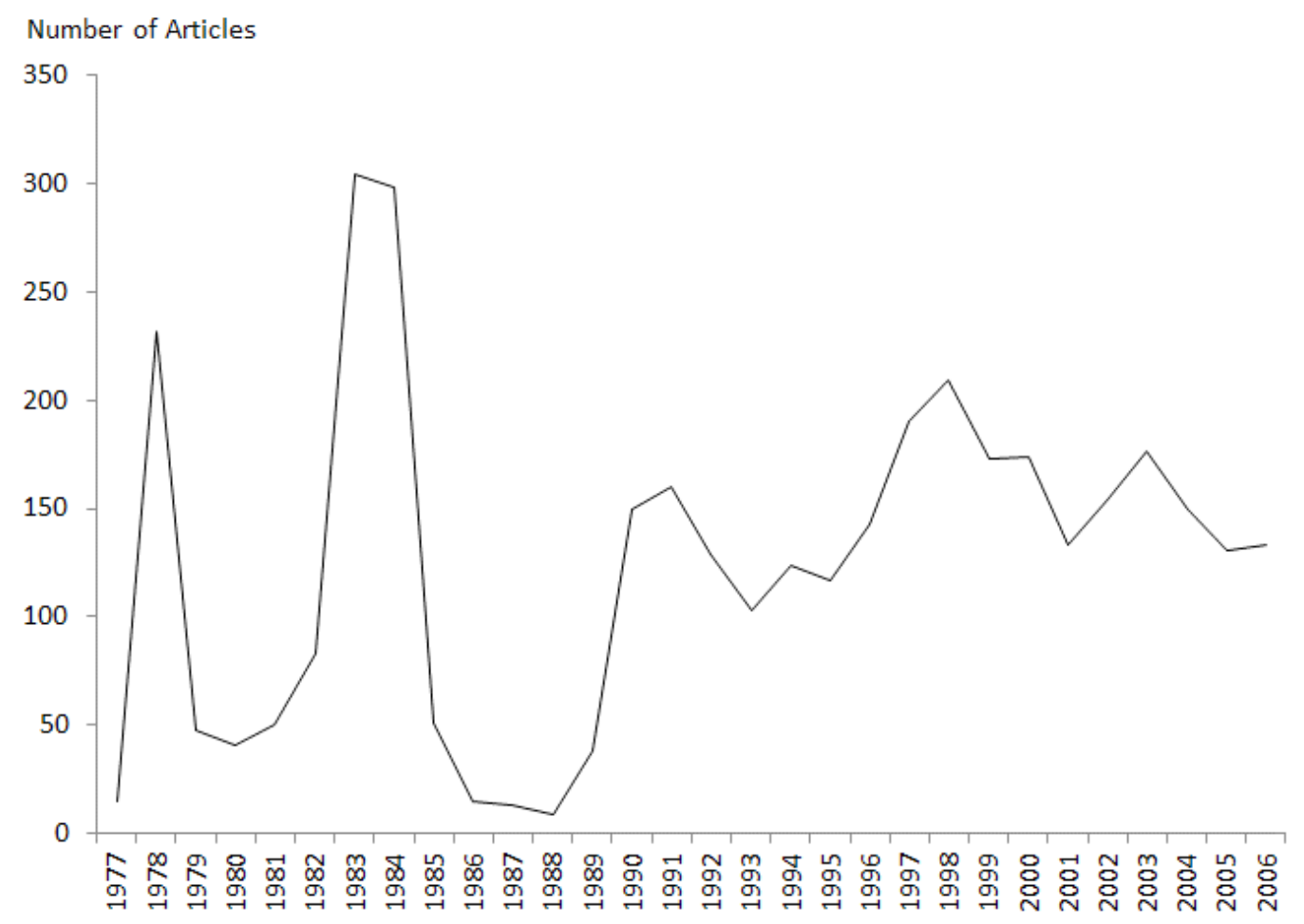

Source: Data collection by the author from Asahi shinbun $1977-2006$

\footnotetext{
28 The consumer credit market is divided up between the different types of lenders: installment sales companies (Shinpan) are under METI control, while credit card companies, CFCs and banks are under MoF control. Because of the segmentation of the consumer credit market there is no centralized database. The lack of shared information about borrowers' credit histories results in excessive lending.

29 Japan Federation of Bar Associations (Nichibenren) reports available for 1994, 1997, 2002, 2005 and 2008

30 We conducted this research in Tokyo in 2012-2013. We used newspapers Asahi and Nikkei database. We built a database with all the articles listed by category depending on the topics and theme of the article, but also the number of words and its visibility. This research helps ud to bypass the main difficulty of our research' subject, which was the access to relevant sources that cover all the period.

31 The major CFCs (Promise, Takefuji, Aiful, Acom) initiated legal proceedings against Asahi Shinbun for using the term "sarakin" instead of "shôhisha kinyu".
} 
We found that political salience was high during each period that was marked by scandals related to the sarakin and that the government usually reacted by lowering the ceiling on interest rates, except in 2004 (Predatory Lending Act, which did not include a revision of the ceiling on interest rates) ${ }^{32}$. (See figure 2)

However, this apparently high level of political salience does not explain why the government did not regulate the market in favor of better borrowers' protection until 2006. In order to understand the subjects covered by the Asahi Shinbun, we have sorted the articles into sub-categories (see figure 3).

1. the category "short news items" includes all articles covering issues of crimes, frauds, hold-ups related to borrowers who have taken credits from sarakin.

2. the category "laws and regulation" includes all articles covering topics related to the legislative and regulatory processes including political and financial collusion between political parties and sarakin.

3. the category "civil society actions" includes all articles covering a broad range of topics related to over-indebtedness, personal bankruptcy and collective actions organized by borrowers' defense groups based on legal expertise. These actions increased during the 1990s in response to the rising number of scandals involving moneylenders (CFCs, small lenders, shôkôron, etc.).

4. the category "consumer credit market" includes all articles covering issues of CFCs business model, growth strategy, etc.

During the initial period of enactment of the Money Lending Business Act (1978-1984), the number of articles covering over-indebtedness as a social issue and civil society actions in defense of borrowers was low in comparison to articles covering the burning issues of borrowers' crime, fraud, and hold-ups. We can deduce from this analysis that general concern about the problem of over-indebtedness was low in the late 1970s to the 1990s. The newspaper nature of coverage of the issues related to sarakin had also nourished a negative perception of indebted borrowers among public opinion.

Figure 3: Analysis of the salience for sarakin mondai by sub-categories

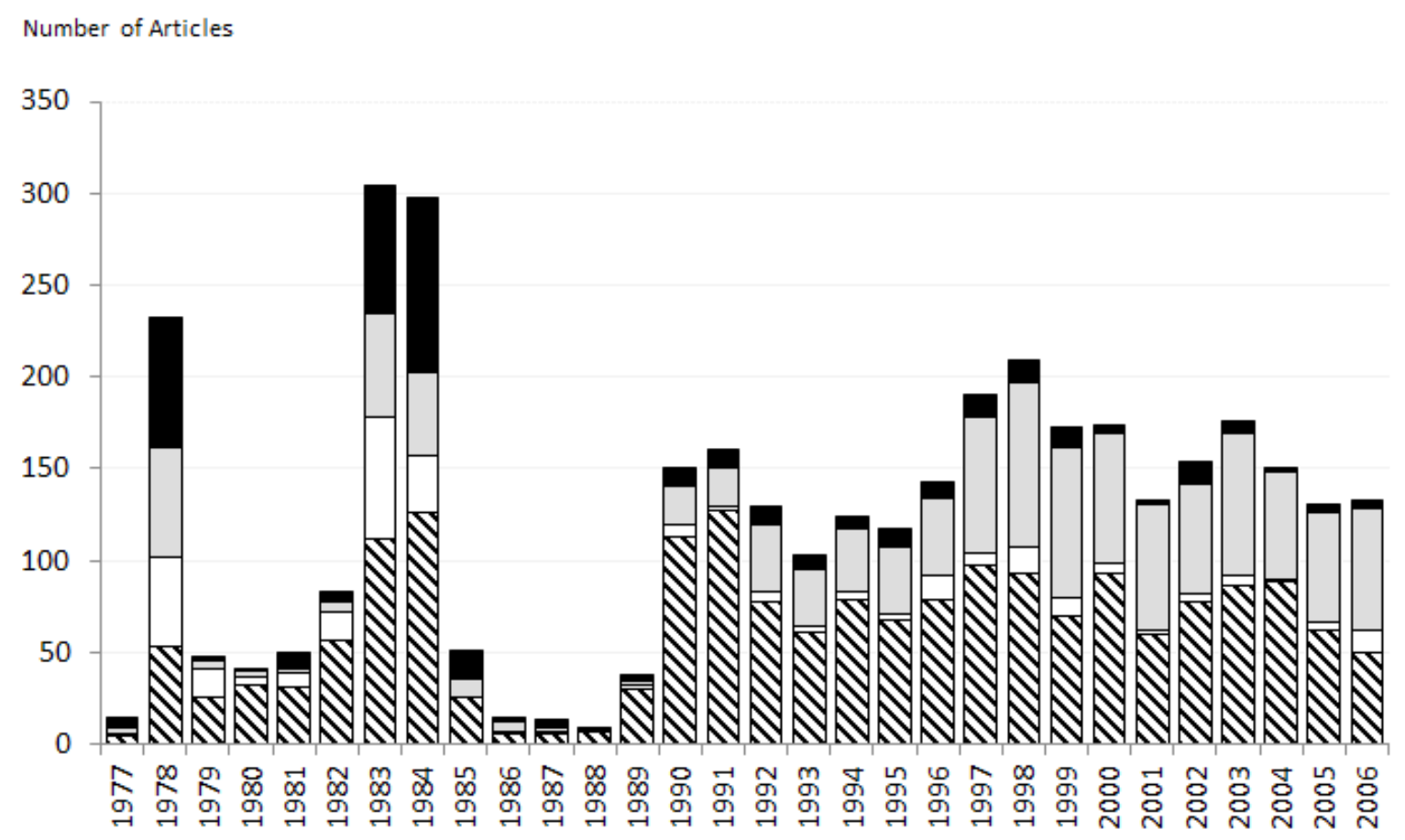

Consumer Credit Market $\quad \square$ Civil Society Actions $\quad \square$ Laws and Regulations $\mathbf{\Delta}$ Short News Items

Source: Data collection by the author from Asahi shinbun 1977 - 2006

In 1978, scandals occurred and forced the government to pass a regulation in 1983; in 1991 the bubble burst and government lowered the ceiling on interest rates to $40.0004 \%$; in 1998, as a result of shôkôron mondai, the government lowered the ceiling on interest rates to $29.2 \%$ ; in 2003, the yamikin scandals occured. 
This low level of interest from journalists regarding the problems of over-indebtedness and personal bankruptcy may be explained by the economic context of stable growth until the mid-1980s, followed by the bubble economy (1989-1991), the maintenance of a high rate of saving and the accumulation of wealth by Japanese households (Horioka, 2012). Personal bankruptcy was seen as an individual problem caused by over-borrowing, attributable to hedonistic behavior on the part of irresponsible consumers ${ }^{33}$. The public did not see personal bankruptcy and over-indebtedness as social issues of general concern. This low perception of the public opinion is also due to the lack of impact of borrowers' advocates to voice their interests in institutional arenas. During the 1970s and the 1980s, local consumer associations and groups of attorneys did not have sufficient experience and knowledge to organize and mobilize the defense and representation of the borrowers' diffuse interests. As we can see on figure 4, the newspapers coverage of social issues related to sarakin was low apart from period during which the implementation of the Moneylenders Law was on the political agenda in 1978 and then in 1983-1984.

\section{Figure 4: Articles in the category "civil society action" sorted into two sub-categories}

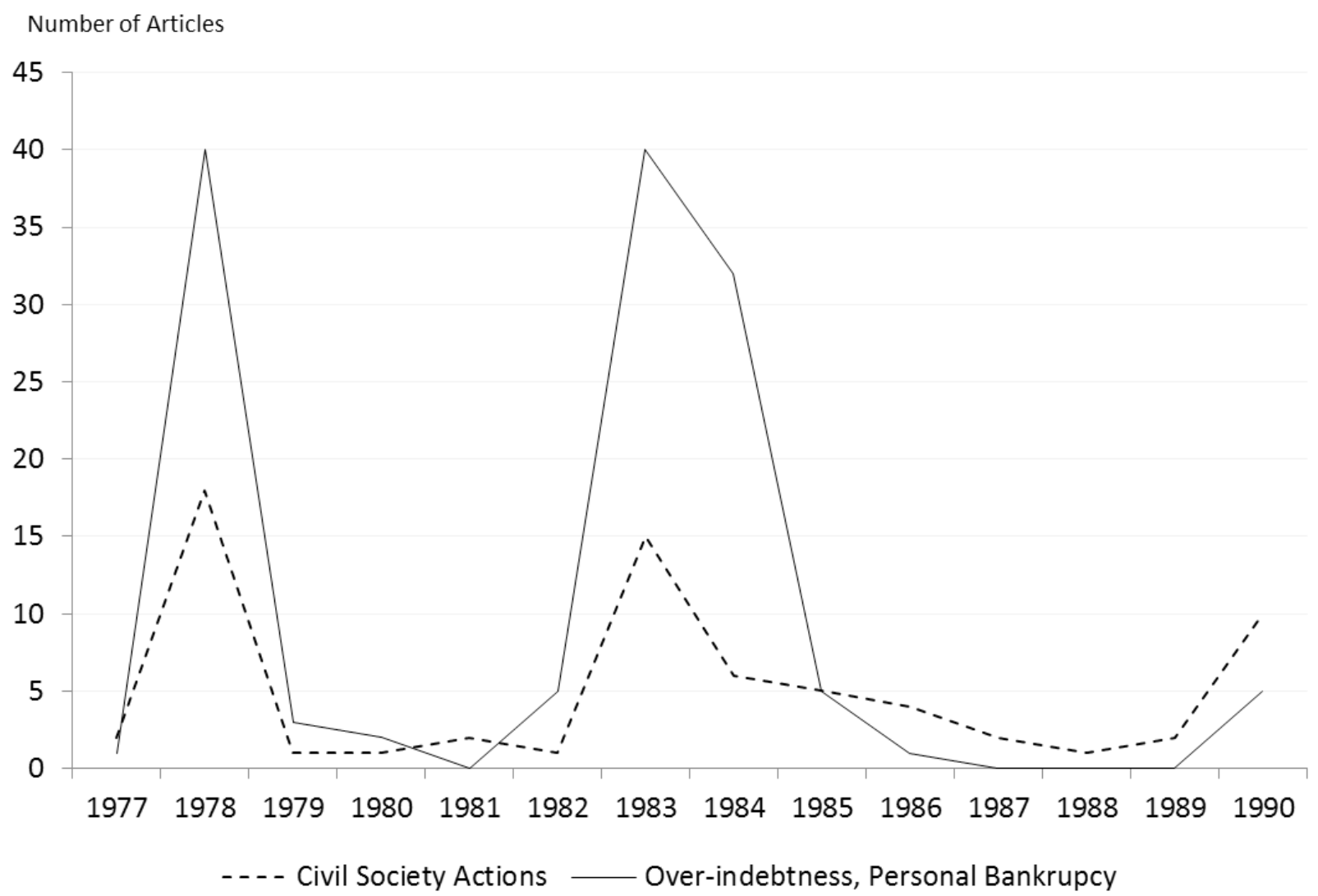

Source: Data collection by the author from Asahi shinbun 1977 - 1990

Utsunomiya Kenji, one of the leaders of the group of lawyers, who organized the defense of borrowers and victims of predatory lending in the early 1980s, pointed out that Japanese lawyers were lacking the experience and training needed to defend consumers in general, and borrowers in particular ${ }^{34}$. This was partly due to the low level of consumer protection rights as Kimura Tatsuya also mentioned, another lawyer involved in the movement against sarakin's abusive lending practices. ${ }^{35}$. Utsunomiya also highlighted the fact that, as many lenders were linked to the Japanese mafia (bôryokudan), articles about the sarakin were widely diffused by the media as a result of the great number of scandals. Although this aspect of the market represented an obstacle to civil society in its effort to mobilize consumer defense, at the same time the high media coverage helped lawyers to communicate more easily through the newspapers about their actions to prevent borrowers from falling victim to illicit practices, and thus becoming over-indebted ${ }^{36}$. But as our research shows, the newspaper coverage of these topics was very irregular until the end of the 1980s reflecting a low interest among the public opinion.

\footnotetext{
33 Interview of a Kimura, a lawyer leader of the movement against sarakin, predatory lending: http://blog.livedoor.jp/bengoshiretsuden/ archives/51321341.html

34 Utsunomiya Kenji' homepage at http://utsunomiyakenji.com/what/

35 Article 1978/4/29; Article Nikkei 1995/11/27

36 Utsunomiya Kenji' homepage at http://utsunomiyakenji.com/what/
} 


\subsection{Collective actions organized by groups of lawyers}

After the bubble burst, borrowers' defense groups composed by local consumers associations, local bar associations, as well as lawyers from the Nichibenren began to better structure their actions at the local and national levels in response to the first significant increase of over- indebtedness and personal bankruptcy caused by over-borrowing (mainly due to credit cards) following the bubble period. By the 1990s, they provided more and more counseling and legal support at the local level, and organized several series of seminars and conferences to mobilize and inform the public about the risk of over-indebtedness, moneylenders illicit practices and the options for legal recourse available to protect debtors from harsh collection practices. In figures 5 and 6 we have sorted all articles related to civil society action and crimes. We observe a decreasing number of articles listed in the category of crimes related to sarakin and in the contrary an increasing number of articles listed in the category of civil society actions that might reflect a rising impact of borrowers defense groups' collective actions. This rising number of articles related to civil society actions also shed light on the possible influence of lawyers over the judiciary power when defending borrowers' cases in courts. Since 2003 judicial power progressively decided to protect more systematically the borrowers.

Figure 5: Articles from the Civil Society Actions' category (1991-2006)

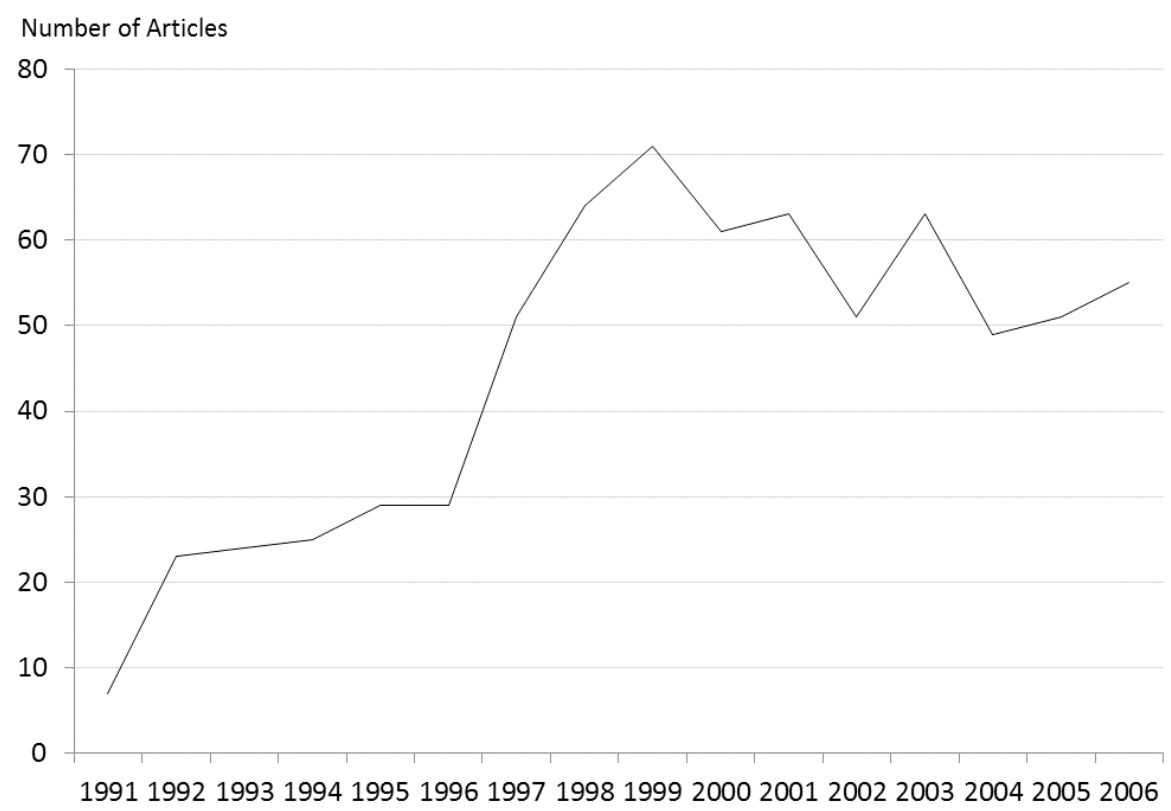

Source: Data collection by the author from Asahi Shinbun 1991-2006

Figure 6: Articles from the Crime's category (1991-2006)

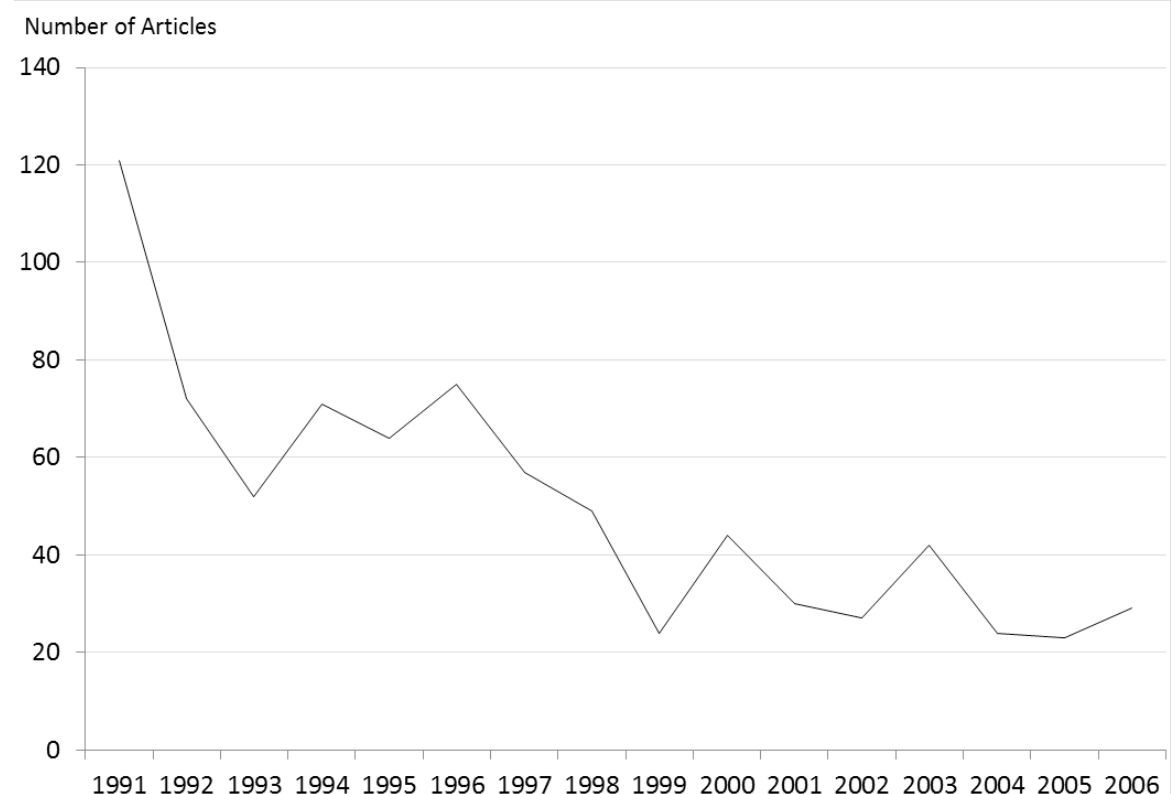

Source: Data collection by the author from Asahi Shinbun 1991-2006 
Between 1996-2004, the government passed the Personal Bankruptcy Law's reform to ease the process of insolvency declaration. This reform helped lawyers to defend over-indebted individuals. During the 1990s and the early 2000s, the number of over-borrowing consumers grew. Data on Japanese bankruptcy filings reflect the growing financial vulnerability of households at the bottom of the income ladder. These data show that the increased rate of bankruptcy filings was mainly due to over-borrowing on the unsecured loan market (see figure 7 ). ${ }^{37}$ Borrowers' defense groups pointed out that illicit practices and excess lending mainly caused the rising number of individuals filing for personal bankruptcy.

Figure 7: Number of personal bankruptcy caused by over-borrowing on the unsecure personal loan sector out of the total number of personal bankruptcy declarations.

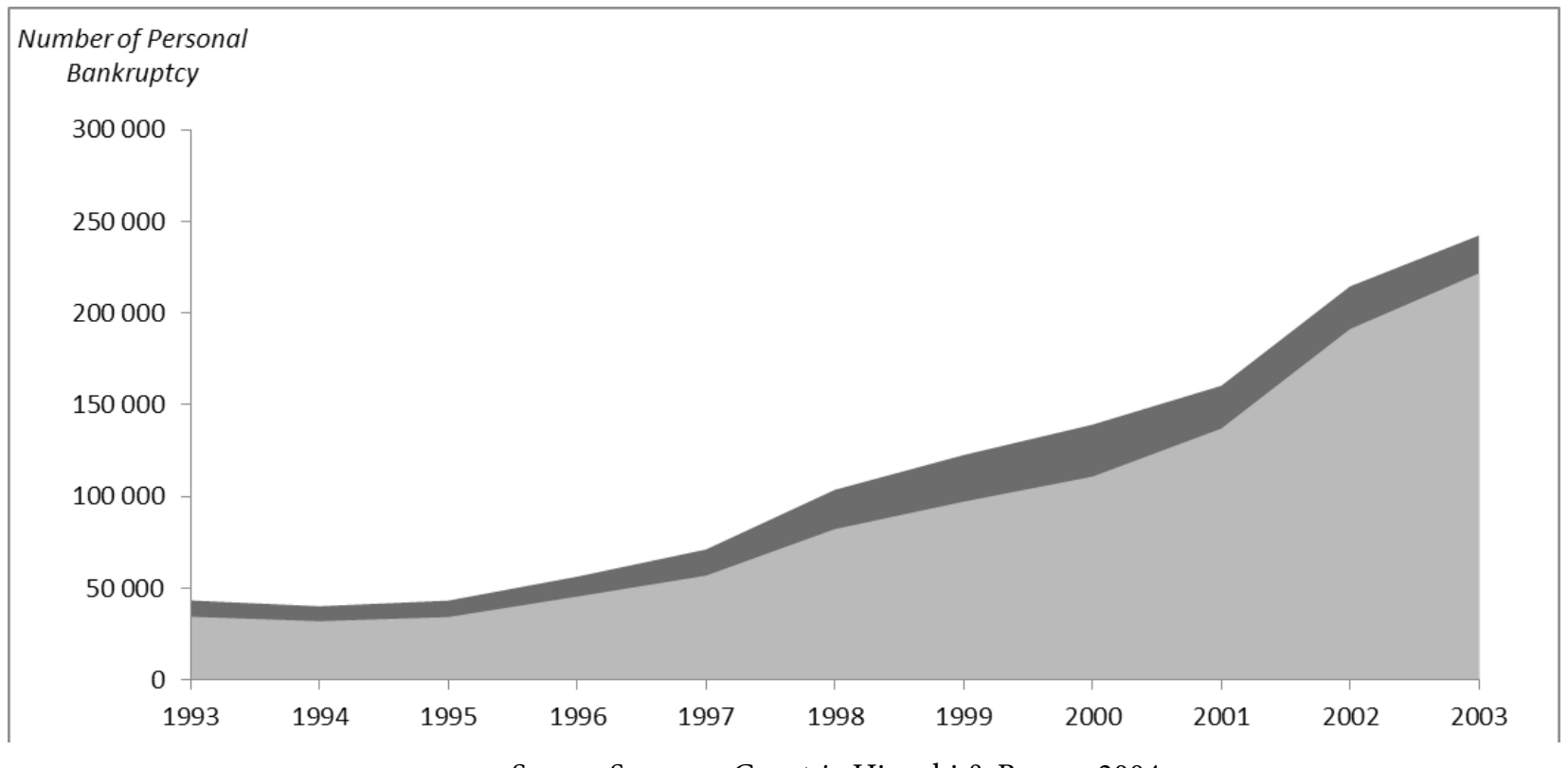

Source: Supreme Court in Higuchi \& Banno, 2004

The increase in the number of articles covering those social issues was also the result of the Courts' series of decisions since 2005, especially the Supreme Court's final decision in January 2006, putting an end to the gray zone lending, which meant that borrowers could claim a refund for excess interest charges. This is known as a "kabarai" claim. (See figure 8)

Figure 8: Increasing number of articles about people filing suit

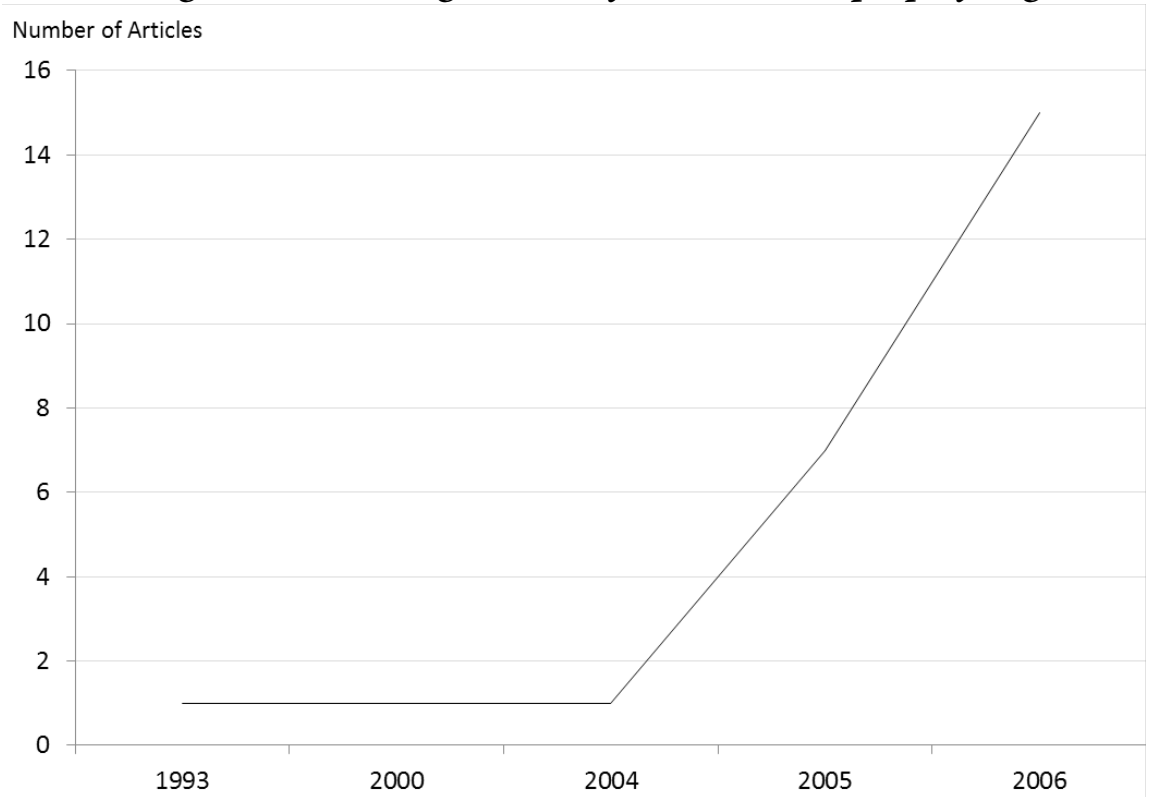

Source: Data collection by the author from Asahi Shinbun 1991-2006

37 These data are compiled by the Japan Federation of Bar Associations (Nichibenren) in reports available for 1994, 1997, 2002, 2005 and 2008: Data for 2005: number of personal bankruptcy filings: 184 000; number of borrowers from sarakin: 14000 000; number of borrowers from more than 5 lenders: 2300 000; number of suicides due to economic and financial vulnerability: 7800. Source: Nichibenren report, 2006. 
Scholars at the Waseda University Institute for Research in Consumer Financial Services pointed out in a survey on the rise of personal bankruptcy filings that the problem was not caused directly by over-borrowing or by high interest rates, but rather because of economic reasons such as lower wages and unexpected events such as job loss or health issues (Higuchi \& Banno, 2004). These results are consistent with other studies published on the problem in the USA. For example, M. White argues that the rise in the number of bankruptcy filings is less a question of financial deregulation than of an economic downturn leading to job loss, lower income and, thus, a heavier burden of debt (White, 2007). She also mentions the case of individual company and small business owners who suffered greatly during the economic crisis and eventually declared personal bankruptcy. In France as well, the government has recognized since 2003 the problem of passive indebtedness (surendettement passif) due to unexpected events such as job loss, bad health or divorce making the borrower unable to reimburse his or her loan (Gloukloviezoff, 2009). In Japan, we observe that borrowers' defense groups led by highly popular personalities such as Utsunomiya Kenji who became a political entrepreneur at the head of the movement for sarakin victims, incorporated their political discourse into a broader context of rising inequality (kakusa shakai), increasing poverty and the phenomenon of the working poor. ${ }^{38}$ The kabarai procedure implemented by the Supreme Court allowed many indebted people to escape temporary their debt.

\subsection{The new law of regulation (kasei kashikingyô hô) and its limits}

In 2006-2010 the government thus revised its policy for protecting consumers. This protection included measures to ensure transparency in consumer credit contracts, to limit excessive or extortionate lending and to ensure better collection and distribution of consumer credit histories, including the centralization of data, and better control over the privacy of personal data. On the one hand, since 2010, Japan's regulation regarding consumer debtors provide a high level of protection across four areas: restrictions on credit advertising, borrowers' rights in contracting (usury cap) and repayment, recourse in case of over-indebtedness, and protection of private financial data, although the establishment of a positive data center for better access to credit is still only under consideration. On the other hand, the full implementation of the revised Money Lending Business Law in 2010 worries academic scholars. As a result of the legal amendments, consumer finance companies have tightened their credit standards for high-risk borrowers and a significant portion of borrowers are excluded from the market, including SMEs. Domoto (2012) points out that regulating interest rates has evident side effects as access to credit is reduced and causes borrowers who are considered high-risk (small business owners, temporary workers, etc.) to be excluded from the market. He observes that the new regulation resulted in an increase of informal loans (family loans and requests for loans on the black market). He also points out the lack of credit counseling services for those who are in difficulty from over-borrowing. Indeed the kabarai provision helps those who are heavily indebted in the short term but cannot solve the general problem of over-indebtedness. He argues that lawyers and judicial scriveners have a virtual monopoly in the area of debt adjustment; in a kabarai claim they receive a contingency fee of $20 \%-30 \%$ of the amount recovered from the moneylenders, encouraging attorneys and other legal professionals to continue to offer kabarai claim services (Domoto, 2012). Following the Supreme Court decision, the seven major CFCs returned almost 1.6 trillion yen and 400 billion of this may well represent the amount received by the attorneys (Ramseyer, 2013). Most of the CFC went bankrupt. Attorneys and legal professionals who deal with debt adjustment made huge profits as the number of kabarai claims increased from $2006^{39}$.

\section{Conclusion}

In this article we analyzed the factors of changes that gradually transformed the Japanese moneylenders business since the 1970s to the 2000s by focusing on the gap between the formal rules and informal practices of lenders that led to excess of lending, abusive and illicit practices as well as over-borrowing and in worst cases debt-related suicides. Our results are the following. First, the revision of the Moneylenders Business Law (2006-2010) is the result of an accumulation of collective actions organized by lawyers to defend borrowers' interests, covered by medias and sustained by the judiciary power as over-indebtedness became a subject of general concern in a period of economic downturn, awareness of rising inequality (kakusa shakai) and growing poverty resulting from greater economic insecurity. The media coverage of several scandals related to moneylenders and CFCs' abusive practices also changed the public opinion's perception about social issues related to sarakin mondai.

\footnotetext{
38 Kondankai (study group 2005-2006) Utsunomiya Kenji's intervention, session 2 - April 27, 2005 available at http://www.fsa.go.jp/singi/ singi_kasikin/singi_kasikin.html

39 General Electric finalizes exit from Japanese consumer Finance, February 26, 2014, Financial Times; This is very similar to what happened in the UK in the early 1990s, when the IVA (Individual Voluntary Agreement) became a popular alternative for over-indebted household consumers who hoped to avoid a formal bankruptcy proceeding. The UK consumer debt management companies, which arranged IVAs for a percentage-based fee, made significant profits and began to promote their services in fairly aggressive marketing campaigns (Trumbull, 2012).
} 
Then, this re-regulation is also the result of gradual institutional changes over a period of 30 years highlighting a shift in power relations such that the groups of lawyers who were not involved in the original design of the law in the late 1970 to early 1980s, then they took it over and turn it to new end (Streeck \& Thelen, 2005). Indeed, by relying on the kabarai procedure, lawyers help indebted or liquidity constrained individuals to gain access to liquidity on the short term. As Ramseyer (2013) argues, lawyers and judicial scriveners won a virtual monopoly in the area of debt adjustment and made huge profit with this new business. The growing legal experience of lawyers to defend borrowers as well as consumers in general allows them to increase their influence in the legislative arena. It also reveals a greater capacity for civil society to organize the provision of better weak interests legal protection. But we also observe that lawyers' collective actions did not contribute to promote social change.

In fact, the group of lawyers argued that over-borrowing was mainly due to unsecured credit lenders' illicit practices. Their arguments have focused on the major CFCs, which have made large profits by charging high interest rates. As a result, the public was more concerned about the lack of morality and justice in the sector than about structural factors of the increasing financial vulnerability among lower income households, irregular workers, small business and VSEs.

Finally, the new regulation has radically modified the complementarity between bank and non-bank sector by putting out of the market almost all lenders (first the small lenders, followed by the large CFCs). However, moneylenders assumed historically a social and economic function by providing loans to high-risk borrowers mainly small business. Since the mid-2000s commercial banks entered the consumer finance market through acquisition of the large CFCs, but they don't provide small loans to high-risk borrowers as small business and consumers, unlike many moneylenders who used to do it at the local level. This lack of efficiency of the credit sector to adapt to the characteristics of the Japanese economy and its financial system reveals the limit of the new law, which was mostly a response to a historical contradictory conflict of interests between two social groups over a profitable business: the loan business followed by the debt adjustment business.

In current research project we are now focusing our attention to analyze the dynamic that would explain the discrepancies between moral objective of an cooperation between weak interest and lawyers and the outcomes in term of new business opportunities supported by political parties as well as new type of collective action and their efficiency to bring social change or not. For example the judiciary procedure - kabarai- was also used as a measure of social policy's substitution by the government to solve the problem of rising over-indebtedness in the short term. It seems that the coalition of interests between moneylenders and dominant political parties has changed in favor of the group of lawyers whose political influence has increased since the mid-2000s. 


\section{References}

ALEXANDER \& KONG (1989), The development and structure of consumer credit in Japan, Rand note publication series

AMABLE \& PALOMBARINI (2009), A neorealist approach to institutional change and the diversity of capitalism, SocioEconomic Review, 7(1): 123-143.

ARON, DUCA, MUELLBAUER, MURATA \& MURPHY (2012), Credit, housing collateral, and consumption: evidence from Japan, the UK and the US, Review of Income and Wealth Series 58, Number 3, September 2012 Press

CALDER K. (1988), Crisis and compensation: public policy and political stability in Japan, 1949-1986, Princeton University

CAPLOVITZ D. (1974), Consumers in trouble: a study of debtors in default, The Free Press Macmillan Publishing Co.

CULPEPPER P.D. (2010), Quiet politics and business power: corporate control in Europe and Japan, Cambridge University Press

DOMOTO H. (2011), Shôhishakinyû no riyô ni kansuru chôsa jôhôsho, Institute For Research On Credit Business, Waseda University

EFFOSSE S. (2014), Le crédit à la consommation en France, 1947-1965: de la stigmatisation à la réglementation, Comité pour l'histoire économique et financière de la France

ENTREPRISE ET HISTOIRE (2010), Consommer à crédit en Europe au XXème siècle, Juin, N.59

FINN M.C. (2003), The Character of Credit. Personal Debt in English Culture, 1740-1914, Cambridge University Press

GARON S. (2011), Beyond Our Means: Why America Spends While the World Savers, Princeton, Princeton University Press

GELPI \& LABRUYERE (1994), Histoire du crédit à la consommation: doctrines et pratiques, Paris, La Découverte

GLICKMAN L.B (1999), Consumer society in American history: a reader, Cornell University Press

GLOUKOVIEZOFF G. (2008), La pauvreté dans les sociétés financiarisées, Regards croisés sur léconomie 2/2008 $\left(\mathrm{n}^{\circ} 4\right)$, p. $117-127$

GO \& NISHIMURA (2005), shôhisha mondai, Keio gijyuku Shuppankai

GORDON A. (2011), Selling the American way: The Singer Sales System in Japan, 1900-1938, Business History Review

GORDON A. (2012), Fabricating consumers: the sewing machine in modern Japan, University of California Press

GOUREVITCH\&SHINN (2005), Political power and corporate control: the new global politics of corporate governance, Princeton University Press

GRAEBER D. (2011), Debt-updated and expanded: the first 5,000 years, Melville House

GUERIN, MORVANT-ROUX \& VILLARREAL (dir.) (2014), Microfinance, Debt and Over-Indebtedness: Juggling with Money, (dir.). Editions Routledge, Londres, Royaume-Uni

HIGUCHI\& BANNO (2004), shôhisha kinyû kokyaku to jikohassan, Institute For Research On Credit Business Waseda University 
HORIOKA C.Y. (2012), Are Japanese Households Financially Healthy, and if so, Why? A Group of Seven (G7) Comparison, The Japanese Economy, Vol. 39, No4, Discussion Paper No. 859.

HORIOKA C. Y. (1990), Why is Japan's household saving rate so high? A literature survey, Journal of the Japanese and International Economies, 4(1): 49-92

HOSHI \& KASHYAP (2004), Corporate financing and governance in Japan: the road to the future, MIT press

HUNTER \& FRANKS (2011), The Historical Consumer, Consumption and Everyday life in Japan, 1850-2000, Macmillan Palgrave UK

HYMAN L. (2011), Debtor nation: the history of America in red ink: the history of America in red ink, Princeton University Press

IWAISAKO T. \& OKADA K. (2009), Understandingthe Decline in the Japanese Saving Rate in the New Millennium, presentation paper in NBER Conference "Japan Project Meeting"(http:// www.nber.org/confer/2009/JPMs09/Iwaisako_ Okada.pdf)

KOBAYASHI \& ONO (2010), nihon no kakei chochiku ritsu, Finance N4, Rapport special disponible: http://www. mof.go.jp/pri/research/special_report/f01_2010_04.pdf

KOLLMAN K. (1998), Outside lobbying: public opinion and interest group strategies, Princeton University Press

KOZUKA \& NOTTAGE (2009), The Myth of the Cautious Consumer: Law, Culture, Economics and Politics in the Rise and Partial Fall of Unsecured Lending in Japan, University of Sidney Legal Studies Research Paper, June (PSE)

LEBARZ C. (Draft) Income Inequality and Household Debt Distribution: A Cross-Country Analysis using Wealth Surveys

MACLACHLAN P. (2002), Consumer Politics in Postwar Japan: The Institutional Boundaries of Citizen Activism, New York: Columbia University Press

NIEMI J., I, R., WHITFORF W.C. (2009), Consumer Credit, Debt and Bankruptcy, Comparative and International Perspectives, Hart Press Ed, Oxford

NISHIMURA T. (2006), Household Debt and Consumer Education in Postwar Japan, dans The Ambivalent Consumer: Questioning Consumption in East Asia and the West, ed. by Garon and Maclachlan, 260-80, Ithaca: Cornell University Press

NORDHAUSEN A. \& HOWELLS G. (2008), The Yearbook of Consumer Law 2009, Ashgate Publishing; second version (2016) Routledge, USA

OLSON M. (1965,), The logic of collective action, Harvard University Press

RAMSEYER M. (2013), Bottom-Feeding at the Bar: Usury Law and Value-Dissipating Attorneys in Japan, Harvard Law School, Cambridge, MA.

SABOURET J-F (2005), La dynamique du Japon, de Meiji à 2015, Editions Saint Simon, Paris

SALA A. (2015), Dette usurière et mouvements sociaux dans le Japon moderne. Vers une institutionnalisation de l'offre de crédit social ?, Histoire et Mesure, Vol. XXX - 1

SHIBUYA R. (1972), Shichiya taisaku rippô no tenkai [Modification de la loi de réglementation appliquée aux prêteurs sur gage], Komazawa daigaku keizai gakurônshû

SHIBUYA R. (2001), Shominkinyû no tenkai to seisaku taiyô [Evolution de la finance populaire et changement de politique], Nihonzushosentâ 
STREECK\& THELEN (2005), Beyond continuity: institutional change in advanced political economies, Oxford University Press

SUDA S. (2006), Karyugui-Shohisha Kinyu No Jittai, Takuma Shinsho, Tokyo

SULLIVAN T.A, WARREN E., and WESTBROOK J.L. (2001), The fragile middle class: Americans in debt, Yale University Press

TRUMBULL G. (2012), Strength in numbers: the political power of weak interests, Harvard University Press

TRUMBULL G. (2014), Consumer Lending in France and America, Cambridge University Press

TRUMBULL G. \& TUFANNO P. (2011), A Brief Postwar History of US Consumer Finance, Business History Review 85, no.3 p.

UTSUNOMIYA K. (2007), tajûsaimu no tadashii kaiketsu hô, Kadensha Tokyo

VOGEL S. (2006), Japan remodeled: how government and industry are reforming Japanese capitalism, Cornell University Press

WILSON J. (1980), The Politics of Regulation, New York, Basic Book

WILSON J. (1973), Political Organization, New York, Basic Book

VAN DER ZWAN N. (2014), Making Sense of Financialization, Socio-Economic Review, 12, 99-129 